\title{
La importancia de la evaluación del desempeño individual: una revisión integradora
}

The Importance of Individual Performance Appraisal: an Integrative Review

A importância da avaliação de desempenho individual:

uma revisão integrativa

Maciel Rodrigues Borges

Universidade Federal de Goiás/Regional

Catalão, Brasil

E-mail: macielrodriguesborges@gmail.com

\author{
André Vasconcelos da Silva \\ Universidade Federal e Goiás, Brasil \\ E-mail: andre.silva.ufg@gmail.com
}

Serigne Ababacar Cissé Ba

Universidade Federal de Goiás, Brasil

E-mail:serigneababacar@hotmail.com

Fecha de recepción: 16/11/2019

Fecha de aceptación: 02/08/2020

\section{Resumen}

La investigación tiene como objetivo analizar las publicaciones sobre la importancia de la evaluación del desempeño individual en la gestión pública a partir de una revisión integradora. Para lograr este objetivo, es necesario comprender que la evaluación del desempeño no es solo una herramienta de control, sino una herramienta extremadamente importante para identificar el potencial de los individuos dentro de una organización, y una herramienta para medir las contribuciones individuales al logro de los objetivos. de la organización. El método utilizado se refiere a una revisión integradora de las bases de datos CAPES, ENAP, SCIELO, SCOPUS y ANPAD, con la adopción de los términos «evaluación del desempeño individual» y «gestión pública». Después de aplicar los criterios de inclusión y exclusión, se identificaron 19 estudios que abordaron el tema de la importancia de la evaluación del desempeño en la

Palabras clave - evaluación del desempeño

- gestión pública

- eficiencia gestión pública. Por lo tanto, el estudio de la evaluación del desempeño en la gestión pública ha mostrado poca investigación y no muestra una tendencia de crecimiento. 
Keywords

- Performance appraisal

- Public Management

- Efficiency

\begin{abstract}
This research work aims to analyze the publications about the importance of individual performance appraisal in public management from an integrative review. In order to achieve this goal, it is necessary to understand that performance appraisal is not only a control tool, but also an extremely important tool for identifying the potential of individuals within an organization, and a tool for measuring individual contributions to the achievement of the objectives of an organization. The method used consists of an integrative review of the CAPES, ENAP, SCIELO, SCOPUS and ANPAD databases, with the adoption of the terms "individual performance appraisal" and "public management". After applying the inclusion and exclusion criteria, nineteen papers that emphasized the importance of performance evaluation in public management were identified. Thus, the study of performance evaluation in public management has received little attention in research and it does not show a growth trend.
\end{abstract}

\title{
Resumo
}

A pesquisa objetiva analisar as publicações sobre a importância da avaliação de desempenho individual na gestão pública a partir de uma revisão integrativa. Para alcançar esse objetivo é necessário compreender que a avaliação de desempenho não e apenas um instrumento de controle, mas uma ferramenta extremamente importante para identificar as potencialidades dos indivíduos dentro de uma organização, e uma ferramenta que permite medir as contribuições individuais para 0 alcance dos objetivos gerais da organização. 0 método utilizado refere-se a uma revisão integrativa nos bancos de dados da CAPES, ENAP, SCIELO, SCOPUS e ANPAD, com a adoção dos termos "avaliação de desempenho individual", e "gestão pública". Após a aplicação dos critérios de inclusão e exclusão foram identificados 19 trabalhos que abordaram a temática da importância da avaliação de desempenho na gestão pública. Sendo

Palavras-chave

- Avaliação de desempenho

- Gestão Pública

- Eficiência assim, 0 estudo da avaliação de desempenho na gestão pública tem apresentado poucas pesquisas desenvolvidas e não demonstra uma tendência de crescimento. 